\title{
血液ガス分析装置における $\mathrm{Ht}$ 值の信頼性について
}

\author{
山梨医科大学医学部付属病院 中央手術部
}

樋口浩二

\section{I . 目 的}

最新の血液ガス分析装置の中には，従来の湘定 項目の他に電解質, Hematocrit (以下, Ht),Total Hemoglobin (以下, tHb), Glucoseなど多 項目に亘り，湘定可能な機種市市販されている。 特に $\mathrm{Ht}$ 測定可能機種では,

1）検体量が少ない（約 $0.2 \mathrm{m \ell ）}$

2 ）測定特間吕短い（約 150 秒)

など，人工心肺装置を操作するうえで利点も大き い。しかし， Ht 湘定原理か機種により異なり，そ の信頼性には若千の疑問が残る。

今回, Ht 測定可能な血液分析装置を使用する機 会を得て，遠心法と比較検討したので報告する。

\section{II. 対象および方法}

\section{1. 血液ガス分析装置}

(1) M $288 ；$ CIBA-CORNING社製（図 1 )。

(2) GEM 6 PLUS ; Mallinckrodt 社製 (図 2 )。

(3) ILBGE; Instrumentation Laboratory 社製 (困 3 )。

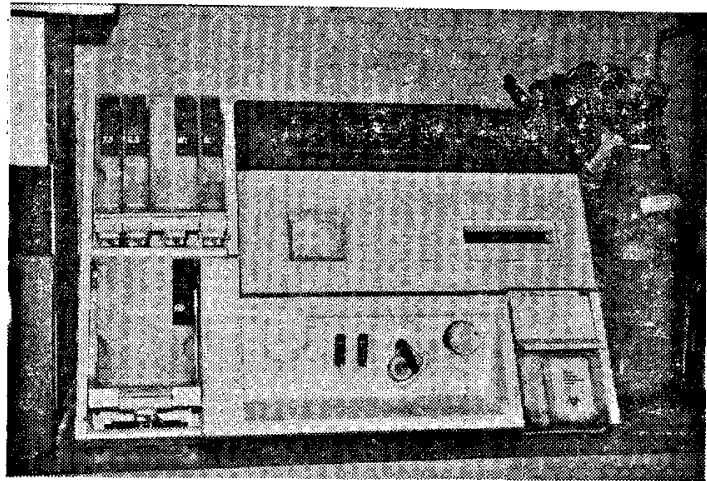

図1M288（CIBA-CORNING社製）

\section{2. 基準 $\mathrm{Ht}$ 值}

各種 $\mathrm{Ht}$ 測定法の中で最屯正確であると評価さ れている方法は, Body hematocrit 法 $^{1)}$ である。 しかしこの方法は，その手技に放射性同位元素を 使用するなど，簡便性および再現性に欠けるため， 今回の実験には適さない。

そこで, Body hematocrit 法に継いで精度が高 く，簡便性および再現性すすぐれている Micro hematocrit 法 ${ }^{1)}$ (以下MH T法：遠心法の一法)

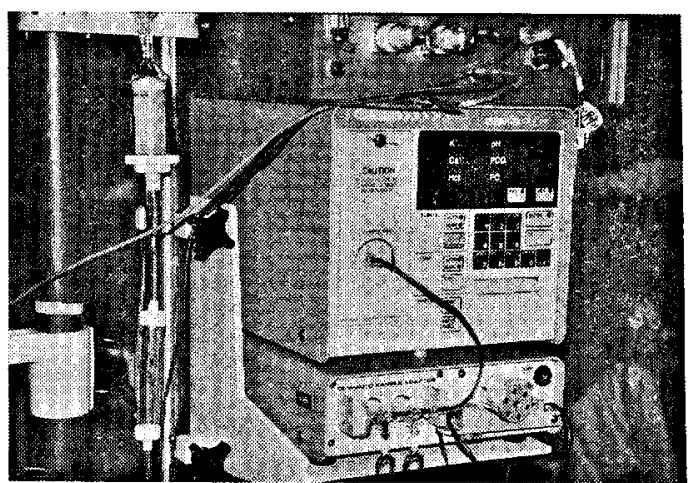

图 2 GEM 6 P L U S (Mallincrodt 社製)

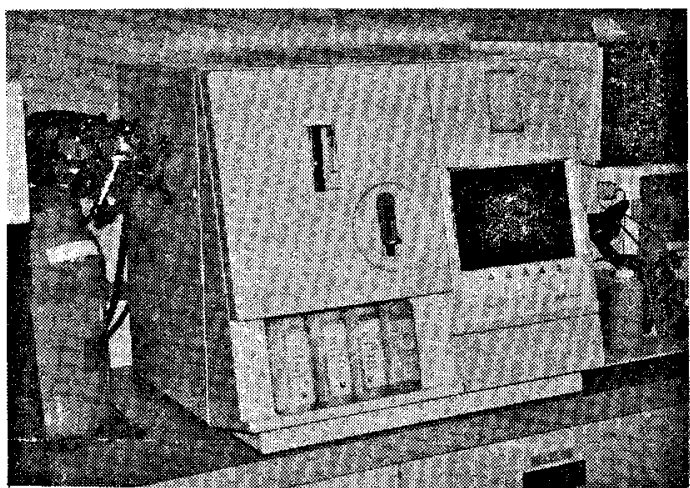

図 3 ILBGE (Instrumentation Laboratory 社笠) 
の Ht 值を基準とした（図 4 ）。

\section{3. 方法}

術中の患者から採血した血液を，MH T 法およ び血液ガス分析装置で同時に测定し比較した。但 し，GEM 6 PLUS は自動サンプリング方式なので， 同時期に採血しMH T 法で測定した Ht 值と比較 した。

\section{III. 菬 果}

三機種ともMH T法との相関は下記の様に極め て良好であった。

(1) M 288 (図 5)

$$
\mathrm{Y}=0.79 X+6.55(\mathrm{n}=33 \quad \mathrm{r}=0.86)
$$

(2) GEM 6 PLUS (図 6 )

$$
\mathrm{Y}=1.04 \mathrm{X}-0.48(\mathrm{n}=88 \quad \mathrm{r}=0.90)
$$

(3) I L B GE (図 7)

$$
Y=0.98 X+0.76(n=63 \quad r=0.97)
$$

\section{IV. 考菠}

今回検討した三機種は極めて信頼性が高かった が，実際の使用経験上それぞれの機種で次の様な 問題点があり，留意すべきであると考える。

\section{M 288}

この機種の Ht 湘定原理は以下の通りである。

1) $\mathrm{tHb}$ 量を測定する。

2 ) 平均赤血球血色素濃度 (mean copuscular hemoglobin concetration : MCHC) の正常值を 利用し，計算にて Ht 値を求める（表 1 )。

$\mathrm{MC} \mathrm{HC}$ とは，貣血の種類を分類する時に用い

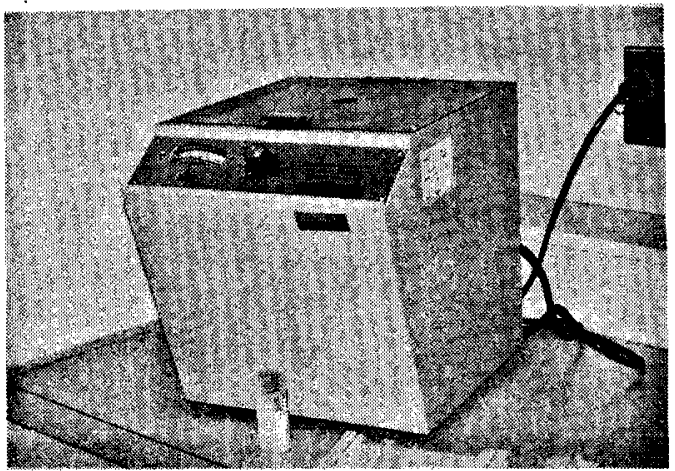

图 4 迹心法

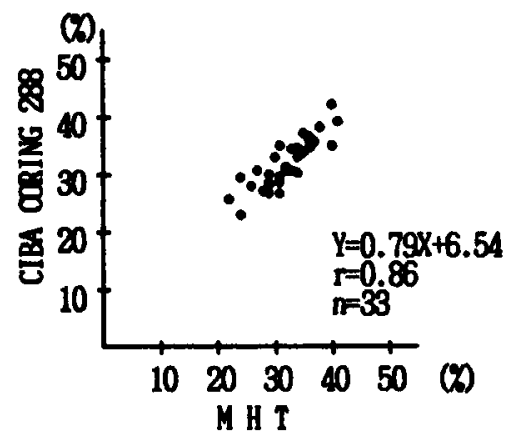

图 5 M 288 とMHTの相明

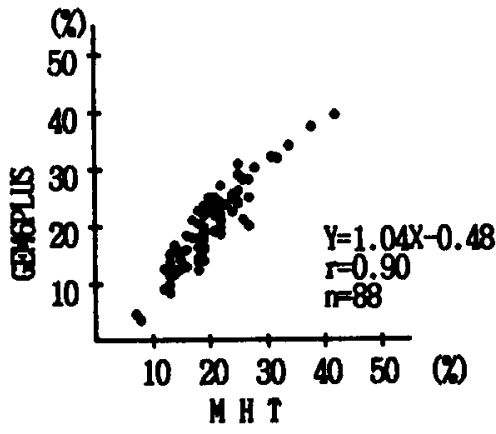

图 6 GEN 6 PLUS 亡MHT の相成

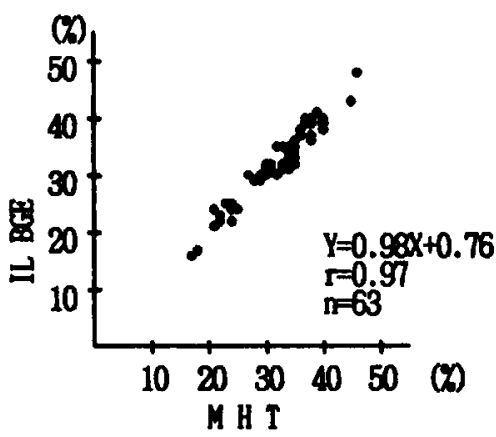

图 7 ILBGE とMHT の相関

表 1 CIBA-CORNING M 288 の神正式

M28 8

ヘマトクリット值の柾正式

$\mathrm{H} \mathrm{t}=\frac{\mathrm{t} \mathrm{H} \mathrm{b}}{34} \times 100$

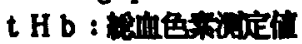

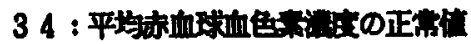


る赤血球平均恒数（mean copuscular constants） の 1 つであり, 個々の赤血球容積に対する $\mathrm{Hb}$ 濃 度を\%で表したあのである。正常值は小児，成人

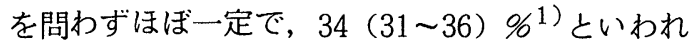
ている。このことから， Hb 濃度が測定出来れば, 計算より $\mathrm{Ht}$ 值を求めるてとが出来る。

しかし，乙れはあくまでもMC HCが正常域に 分布していることが条件であり，MC HCが正常 域外を示すような疾患では成り立たない。

例えば, $\mathrm{Hb}=10 \mathrm{~g} / \mathrm{d} \ell, \mathrm{Ht}=40 \%$ (M H T 法) の場合, 実際のMC HC は25\%である。しかし, 乙の機種の場合, MC HC は常に一定值 (34\%) であるから $\mathrm{Ht}=(10 / 34) \times 100=29.4 \%$ とな り, MH T 法と比較して約10\%の誤差を生じる。

従って; 測定された $\mathrm{Hb}$ 濃度が低值を示す時に は, 求められた $\mathrm{Ht}$ 值を非常に大きな誤差を含ん でいるということを充分に理解して使用する必要 がある。

\section{GEM 6 PLUS}

この機種の Ht 測定原理は下記の通りである。

1 ）血液を電導物質，赤血球を電気抵抗と見な す。

2 ）血液中の電気抵抗值を測定し, $\mathrm{Ht}$ 值に換算 する。

血液中の諸条件が一定ならば，抵抗值は $\mathrm{Ht}$ 值 に相関する。従って，相関式を利用すれば電気抵 抗值から $\mathrm{Ht}$ 值を求めることが出来る。

しかし，乙の方法では血浆中の電導物質，特に 電解質 $\left(\mathrm{Na}^{+} \mathrm{K}^{+}\right)$の濃度の増減により電気抵抗值 に変動を来し, 誤差を生じる。

当施設では, 補正式 (表 2 ) を作製しての問題 が解決しているが，乙の機種には補正に必要な $\mathrm{Na}^{+}$が測定出来ないという欠点がある。

\section{I L BGE}

この機種の Ht 測定原理はGEM 6 PLUS と同様 に, Ht の差より血液中の電気抵抗値が異なること を利用している。しかも $\mathrm{Na}^{+}$が測定可能なととお
表 2 GEM 6 PLUS の補正式

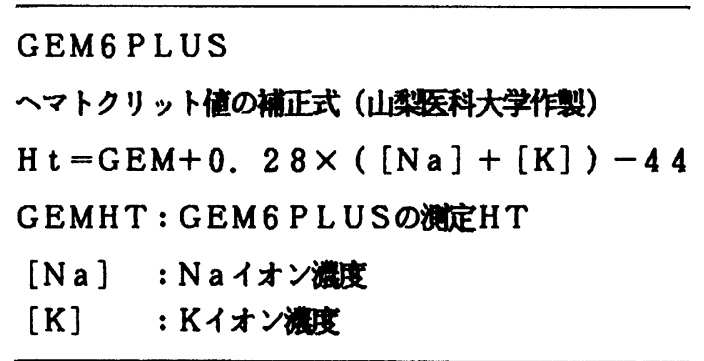

表 3 ILBGE の補正式

I L BGE

ヘマトクリット值の㭪正式

$\mathrm{H} t=\mathrm{f} \times\left(\frac{1}{140}\right)$

f : 不 明

nis : 不 明
よび独自の補正式（表 3 ）を有しているなど, GEM 6 PLUS より 機能的に優れている。

しかし，自動校正機種にも関わらず，Htだけは 手動校正であること，および $\mathrm{Ht}$ 用コントロール液 でdata を毎日 cheak しなければ臨床值の信頼性が 保てないなど,メンテナンスに煩わしさを感じる。

\section{V. 結 語}

機種または測定原理により特有の注意事項を有 するが，それらは全て日常に打いてクリアする事 が可能であり, 今回検討した機種の Ht は充分に 信頼できると考える。

\section{参考文献}

1）金井 泉：臨床検查法提要第29版，血液検查， 235 248 , 金原出版, 東京. 